\title{
(द)

\section{Regjeringens «koronakommisjon» er lite representativ og har inhabil leder}

DEBATT

\section{ROLF KÅRESEN}

Rolf Kåresen er dr.med., spesialist i generell kirurgi og i bryst- og endokrinkirurgi, professor emeritus ved Universitetet i Oslo og tidligere sjeflege ved Oslo universitetssykehus, Ullevål.

Forfatteren har fylt ut ICMJE-skjemaet og oppgir ingen interessekonflikter.

\section{SVEN ERIK GISVOLD}

Sven Erik Gisvold er dr.med., spesialist i anestesiologi, professor emeritus ved NTNU og tidligere avdelingssjef ved Avdeling for anestesi ved St. Olavs hospital.

Forfatteren har fylt ut ICMJE-skjemaet og oppgir ingen interessekonflikter.

\section{HANS ERIK HEIER}

E-post: heheier@online.no

Hans Erik Heier er dr.med., kandidat i helseadministrasjon, spesialist i immunologi og transfusjonsmedisin, professor emeritus ved Universitetet i Oslo og tidligere avdelingsoverlege ved Avdeling for immunologi og transfusjonsmedisin ved Oslo universitetssykehus, Ullevål. Forfatteren har fylt ut ICMJE-skjemaet og oppgir ingen interessekonflikter.

Regjeringen har oppnevnt en kommisjon som skal vurdere håndteringen av koronaepidemien. De fleste medlemmene er politikere eller administratorer. Blant de tre legene er bare én aktiv kliniker. Sykepleierne er ikke representert. Lederens habilitet er tvilsom, og mandatet er både uklart og begrenset.

I en kronikk i Tidsskriftet primo mai 2020 (1) konkluderte vi med at "covid-19-pandemien gir viktig lærdom om hvordan Norge bør innrette helse- og sykehusvesenet heretter», og foreslo en utredning bl.a. av hvilke konsekvenser disse erfaringene skulle få for planen for nye sykehus. Til tross for en meget rask godkjenningsprosess i Tidsskriftet kom kronikken på etterskudd i forhold til regjeringens oppnevning av en «koronakommisjon». Ved å handle så raskt har regjeringen kunnet legge all negativ vurdering av pandemihåndteringen død i første omgang, og den har unngått debatt om kommisjonens sammensetning og mandat. Stortingets opposisjon, representert ved Jonas Gahr Støre, uttalte at den var vel fornøyd med kommisjonen, og at professor emeritus Stener Kvinnsland er en utmerket leder. Vi er uenige i begge deler.

\section{Leder med tvilsom habilitet}

Kvinnsland har, som administrerende direktør for Helse Bergen fra 2003 og som styreleder for Oslo universitetssykehus i en årrekke, vært ansvarlig for beslutninger av stor betydning for landets helsemessige beredskapssituasjon. Han har utvilsomt erfaring nok til å kunne lede kommisjonen, men fordi han har så mye å forsvare, er habiliteten hans meget tvilsom. 


\section{Mangelfull kompetanse}

Blant medlemmene i kommisjonen finnes bare én lege med spesifikk kunnskap om infeksjonsmedisin (2). Leger som til daglig har ansvar for beredskap i sykehusene og som har hatt "støvlene på» under pandemien, burde vært mye bredere representert. Like kritikkverdig er det at sykepleierne, som har en sentral posisjon både i sykehus og i kommunehelsetjenesten, overhodet ikke er representert. Begge deler er dypt skuffende. Kommisjonen representerer i overflod det politisk-administrative komplekset i vårt land, men dessverre lite annet.

Mandatet unnlater å røre ved konkrete spørsmål som regjeringen vet er både viktige og kontroversielle

\section{Lite spesifikt mandat}

Mandatet skuffer også. Det er meget rundt. Med litt velvilje kan man si at det dekker de to første av fem punkter på lista i vår kronikk (1): behovene for beredskapslagre og egenproduksjon av smittevernutstyr og medikamenter. Men våre tre siste punkter - som dreier seg om sengetall i sykehus, hvordan sykehus bør bygges for å møte behovene som oppstår når pandemier treffer oss, og behovet for kompetanseoppbygging hos personale på alle nivåer - er ikke nevnt med et ord. Mandatet unnlater altså å røre ved konkrete spørsmål som regjeringen vet er både viktige og kontroversielle.

\section{Lave forventninger til resultatet}

Våre forventninger til verdien av det kommisjonen skal legge frem i mars neste år, er derfor lave. Beklageligvis har Stortinget unnlatt å gripe inn. Det burde ha sørget for å gi kommisjonen en leder hvis habilitet ikke kan trekkes i tvil. Det burde også ha sørget for bredere og mer adekvat sammensetning av kommisjonen og et mer omfattende og spesifikt mandat. Kvinnsland-kommisjonen kan ikke anses som sterk, uavhengig og objektiv slik som Gjørv-kommisjonen, som vurderte responsen på terroren i regjeringskvartalet og på Utøya i 2011. Regjeringen ønsker seg tydeligvis en utredning fri for kritikk og utfordringer av betydning, og det kommer den til å få. Et annet resultat vil jo kunne slå negativt ut $\mathrm{i}$ stortingsvalget!

\section{LITTERATUR:}

1. Kåresen R, Gisvold SE, Heier HE. Beredskap og sykehusbygging: Hva bør vi lære av covid-19? Tidsskr Nor Legeforen 2020;140. doi:10.4045/tidsskr.20.0286. [CrossRef]

2. Koronakommisjonens medlemmer og mandat. https://www.regjeringen.no/no/aktuelt/dep/smk/pressemeldinger/2020/regjeringen-oppnevner-koron akommisjon/koronakommisjonens-medlemmer/id2699484/ Lest 25.5.2020.

Publisert:3. juni 2020. Tidsskr Nor Legeforen. DOI: 10.4045/tidsskr.20.0446

Mottatt 17.5.2020, første revisjon innsendt 22.5.2020, godkjent 25.5.2020.

(C) Tidsskrift for Den norske legeforening 2020. Lastet ned fra tidsskriftet.no 